\title{
Announcements
}

INTERNATIONAL CONFERENCE ON NEURAL NETWORKS: BIOLOGICAL COMPUTERS OR

\section{ELECTRONIC BRAINS}

Lyons (France); March 6-8, 1990. Enquiries to:

AFCET (Conference Department)

156, Boulevard Peréire

75017 PARIS

FRANCE

(Tel. 33-1, 476624 19; fax 33-1, 426793 12)

\section{ADVANCED PRODUCTIVITY EXPOSITION (APEX) AND MANUFACTURING PRODUCTIVITY CONFERENCE}

Charlotte, North Carolina (USA); March 6-8, 1990. Enquiries to:

\section{SME \\ 1 SME Drive \\ DEARBORN \\ MI 48121 \\ USA}

(Tel. 313-271 1500; telex 297742 SME UR (via RCA); fax 313-271 2861)

NOTE: Similar events will take place in Philadelphia (April 10-12, 1990) and West Springfields (Massachusetts) (May 22-24, 1990).

\section{ONE-DAY SEMINAR ON TECHNOLOGY}

MANA GEMENT (Battelle)

London (UK); March 12, 1990. Enquiries to:

Ms Renate Siebrasse, Operations Manager

Battelle Institute Ltd

15, Hanover Square

LONDON W1R 9AJ

UK

(Tel. 01-493 0184; telex 23773; fax 01-629 9705)

NOTE: A similar event will take place in Paris (France) on March 15, 1990.

\section{OPEN SYSTEMS INTERCONNECTION (OSI) DEMONSTRATION AT CeBIT '90}

Hannover (West Germany); March 21-28, 1990. Enquiries to:

\section{C.G. Cooper}

Level-7 Ltd

Guildgate House, The Terrace

WOKINGHAM

Berks. RG11 1BP

UK

$(+440734771299 ;$ fax +440734771740$)$
COURSE ON ADVANCES IN HARDWARE/SOFTWARE RELIABILITY/MAINTAINABILITY ENGINEERING (UCLA)

Los Angeles, California (USA); March 26-30, 1990. Enquiries to:

Engineering Short Courses

10995 LeConte Ave.

LOS ANGELES

CA 90024

USA

(Tel. 213-825 1047)

TENTH EUROPEAN MEETING ON CYBERNETICS AND SYSTEMS RESEARCH

Vienna (Austria); April 17-20, 1990. Enquiries to:

Robert Trappl

Dep. of Medicine and AI

University of Vienna

Freyung 6/2

A-1010 VIENNA

AUSTRIA

(Telex 75312311 ofai a; fax +43222630652 ;

tel. +4322253532810 )

\section{FIRST EUROPEAN CONFERENCE ON COMPUTER} VISION

Antibes (France); April 23-27, 1990. Equiries to:

C. Juncker

Bureau des Relations Exterieures INRIA-Sophia Antiopolis

2004 Route des Lucioles

06565 VALBONNE Cedex

FRANCE

(Telex 970 050f; fax 3393657766 )

THE 1990 IEEE INTERNATIONAL CONFERENCE ON ROBOTICS AND AUTOMATION

Cincinnati, Ohio (USA); May 13-18, 1990. Enquiries to:

A.J. Kolvo

School of Electrical Engineering

Purdue University

WEST LAFAYETTE

IN 47907

USA

THE ASIA-PACIFIC INDUSTRIAL AUTOMATION EXHIBITION AND CONFERENCE-IA '90

Singapore; May 23-26, 1990. Enquiries to:

Singapore Industrial Automation Association 61A Science Park Drive Blk 1

Singapore Science Park

SINGAPORE 0511

(Tel. 779 7311; fax 779 5129) 


\section{INTERNATIONAL CONFERENCE ON}

MANUFACTURING SYSTEMS AND ENVIRONMENT

Tokyo (Japan); May 29-June 1, 1990. Enquiries to SME, as above.

\section{THIRD NATIONAL AUSTRALIAN CONFERENCE ON} ROBOTS FOR THE 1990's

Melbourne, Victoria (Australia); June 3-6, 1990. Enquiries to:

Australian Robot Association

G.P.O. Box 1527

SYDNEY NSW 2001

AUSTRALIA

\section{SECOND EUROPEAN CONFERENCE ON SOFTWARE}

\section{QUALITY}

Oslo (Norway); May 30-June 1, 1990. Enquiries to:

The Norwegian Computer Society (Rolf Westgaard)

Tel. 02-37 0263 or $02-843941$

\section{SECOND INTERNATIONAL CONFERENCE ON} ECONOMICS AND ARTIFICIAL INTELLIGENCE

Paris (France); July 2-6, 1990. Enquiries to AFCET, as above.

\section{EIGHTHS CISM-IFTOMM SYMPOSIUM ON THEORY} AND PRACTICE OF ROBOTS AND MANIPULATORS

Cracov (Poland); July 2-6, 1990. Enquiries to:

Professor A. Morecki

Warsaw University of Technology

Al. Niepodleglosci 222

00663 WARSAW

POLAND

(Telex 813307 PW PL)
JAPAN-USA SYMPOSIUM ON FLEXIBLE

AUTOMATION: A PACIFIC RIM CONFERENCE

Kyoto (Japan); July 9-11, 1990. Enquiries to

Professor Tohru Watanabe

c/o The Institute of Systems, Control and Information Engineers

Kink-Chido Hatsumei Center

Yoshida-Kawahara-Cho 14

Sakyo-ku, KYOTO 606

JAPAN

NOTE: Information may also be obtained from Professor D.A. Dornfeld, Dept. of Mechanical Engineering, University of California, Berkeley, CA 94720 , USA.

INTERNATIONAL NEURAL NETWORK CONFERENCE Paris (France); July 9-13, 1990. Enquiries to:

Nina Thellier N.T.C.

INNC-90-Paris

19 , rue de la Tour

75116 PARIS

FRANCE

(Tel. 33-1, 45-25-65-65; fax 33-1, 45-25-24-22)

\section{FIFTH WORLD CONFERENCE ON COMPUTERS IN} EDUCATION, WCGE ' 90

Sydney (Australia); July 9-13, 1990. Enquiries to

Carmen Fernandez Chamizo

Departamento de Informatica y Automatica

Facultad de Fisicas, Univ. Compultense

28040 MADRID

SPAIN 